\title{
Human rabies post-exposure prophylaxis relative to the disease epidemiological status
}

\author{
Tratamento antirrábico humano pós-exposição \\ em relação à situação epidemiológica da doença
}

Bruno Fonseca Martins da Costa Andrade ${ }^{1}$

Taísa Santos de Melo Andrade ${ }^{2}$

Luzia Helena Queiroz ${ }^{1}$

${ }^{1}$ Programa de PósGraduação em Ciência Animal, Faculdade de Medicina Veterinária, Universidade Estadual Paulista. R. Clóvis Pestana 793, Dona Amélia. 16050-680 Araçatuba SP Brasil.bfmca@hotmail.com

${ }^{2}$ Santa Casa de Misericórdia de Araçatuba. Araçatuba SP Brasil.

\begin{abstract}
This study evaluated the prophylactic measures adopted after attacks by dogs and cats in the main city of Northwester São Paulo State, based on the technical manual for post-exposure treatment, considering the not controlled (19901996) and controlled (1997-2010) rabies status. A retrospective analysis was done using the data from the SINAN records (W64-CID10) between 1990 and 2010. In most cases, the accidents were mild (76.9\%), and biting animals were healthy (75.4\%); therefore, no treatment was needed in $53.3 \%$ of the cases. In $64.6 \%$ of cases, the prescribed PEP treatment was inappropriate. The most indicated PEP treatments consisted of vaccine and RIG (43.4\%), and either three doses of mouse brain vaccine or two doses of cell culture vaccine $(76.5 \%)$, during the not controlled and controlled rabies periods, respectively. The treatment was more appropriate and followed the technical recommendations during controlled rabies periods compared to not controlled $(p<0.0001)$ periods. However, excessive application of RIG and rabies vaccine was observed in both periods. Key words Rabies, Animal aggression, Post-exposure prophylaxis, Immunization schedule, Dogs
\end{abstract}

Resumo O objetivo da presente pesquisa foi avaliar a conduta profilática adotada após agressões por cães e gatos no município de Araçatuba, SP, com base no Manual Técnico de Tratamento Antirrábico Humano e considerando-se as situações de raiva não controlada (1990-1996) e controlada (1997-2010). Foi realizada uma análise retrospectiva dos dados das fichas do SINAN (W64CID10) preenchidas pelo serviço de atendimento antirrábico no período de 1990 a 2010. Na maioria dos casos os acidentes foram leves (76,9\%) e os animais agressores estavam sadios (75,4\%), resultando em $53,3 \%$ de dispensa do tratamento. Em $64,6 \%$ dos casos em que houve indicação de tratamento esta foi considerada inadequada. No periodo de raiva não controlada houve maior indicação do tratamento com vacina e soro $(43,4 \%)$ e no de raiva controlada o tratamento com três doses de vacina Fuenzalida e Palácios ou duas doses de vacina de cultivo celular (76,5\%). No período de raiva controlada as condutas foram mais adequadas, segundo as recomendações técnicas, do que no período de raiva não controlada $(p<0,0001)$, embora, em ambos os períodos, tenha se observado uma aplicação excessiva de soro e vacina.

Palavras-chave Raiva, Agressão por animais, Tratamento pós-exposição, Esquemas de imunização, Cães 


\section{Introduction}

Rabies is one of the oldest infectious diseases, first described at least four thousand years ago ${ }^{1}$ and has worldwide distribution. It is a viral disease characterized by acute encephalomyelitis that affects all mammalian species including humans ${ }^{2}$.

Human infection occurs when a person is bitten and exposed to the virus present in the saliva of an infected animal. Since the virus is introduced into the body it reaches the peripheral nerve endings and begins the migration to the central nervous system (CNS), when clinical symptoms of the disease can be identified. After the symptoms appear, prophylactic measures are useless and rabies usually results in muscle paralysis and death of both human and other mammals, due to respiratory arrest ${ }^{3}$.

The urban cycle of the disease, maintained by the canine-adapted variant of the rabies virus, remains the most important factor for the persistence of human rabies in the majority of developing countries where canine rabies remains endemic. Although dogs are still the main reservoir, with high epidemiological relevance for transmission ${ }^{4}$. In Brazil bats were responsible for $70 \%$ of the human rabies cases in the decade of 2004-2013, followed by dogs with $22 \%$ of the human cases $^{5}$. Since the 2000-year dog rabies, transmitted by the canine-adapted variant, presented a considerable decrease and was eliminated in the South and Southeast region of Brazil, including São Paulo State ${ }^{6}$.

Post-exposure prophylactic (PEP) treatment in humans is indicated when the risk of infection by the rabies virus is present. This risk assessment defines the procedure to be adopted ${ }^{7}$. Exposures are classified as mild or severe according to the site of the bite and the type of injury ${ }^{3}$. Regarding the aggressor species, if it is a dog or cat, it is necessary to consider its health status at the time of aggression, and the possibility of being followed up for a period of 10 days $^{3}$.

When exposure occurs in a geographical area where the epidemiological status of rabies is not controlled and the wound is severe, PEP treatment should start immediately, even during the animal observation period. On the other hand, no PEP treatment is required even when exposure/wound is serious, if the animal is from an area where rabies is controlled, and the dog or the cat can be observed for 10 days $^{7}$.

The PEP treatment consists on the use of rabies vaccine, and in cases of severe wounds, the concurrent use of equine rabies immunoglobulin (e-RIG) or human rabies immunoglobulin (h-RIG) ${ }^{3}$. However, in some cases of dog aggression in Brazil, post-exposure procedure are not properly indicated ${ }^{8-11}$. In the 90's the São Paulo Northwestern region presented a canine rabies epidemic, involving 13 municipal districts, including Araçatuba (SP), with the death of two individuals, 345 positive dogs and 21 positive cats ${ }^{12}$.

The hypothesis that in the period of uncontrolled rabies there would be a greater number of registered aggressions and PEP treatment indications led us to the idealization of this study. Thus, the objective of this research was to determine whether PEP conduct adopted (no treatment or indication of any treatment) after dogs and cats aggressions, were appropriate or not, based on the Technical Manual of Human Anti-Rabies Treatment of the Ministry of Health and the epidemiological situation of disease in the county of Araçatuba - SP, in the period 1990-2010.

\section{Methods}

This retrospective study analyzed the data from the files of the Epidemiological and Health Surveillance Department (EHSD) of Araçatuba, SP, Brazil, between 1990 and 2010. This city is the county seat of the northwestern region of São Paulo state, with approximately 180,000 inhabitants and about 1.8 dogs for every 10 inhabitants in the urban area ${ }^{13}$ and had an epizootic canine rabies in the period from 1993 to $1996^{12}$.

The evaluated data were recorded in the compulsory notification forms of the Notifiable Diseases Information System (Sistema Nacional de Agravos de Notificação - SINAN), Human anti-rabies Service, CID10 - W64, composed by six sections with 66 fields. We chose the following fields from the total: type of rabies virus exposure; location; wound; type of injury; history of anti-rabies treatment; attacking animal species; initial and final animal condition; recommended treatment and indication of RIG.

The recommended PEP treatment was evaluated in the light of the technical standards of human rabies prophylaxis of the Brazilian National Rabies Prevention Program of the Ministry of Health in effect during the study period ${ }^{3,7,14}$. The injury, the treatment and the adequacy of the adopted conduct ${ }^{9}$ were classified based, on the initial and final animal condition, rabies epidemiological situation of the city, the injury nature and the prescribed treatment (Chart 1). 
Chart 1. Classification of variables regarding the wound characteristics, the recommended treatment and the adopted conduct after human dog/cat aggression.

\begin{tabular}{|c|c|c|}
\hline Variable & Classification & Characteristics \\
\hline \multirow{2}{*}{$\begin{array}{l}0 \\
3 \\
0 \\
3\end{array}$} & Mild & Single and superficial wound on the trunk and limbs \\
\hline & Severe & Multiple and deep wound, lacerating on the head, mucosa, hands and feet \\
\hline \multirow{7}{*}{$\begin{array}{l}\frac{\tilde{U}}{0} \\
\stackrel{\Xi}{0} \\
0 \\
0\end{array}$} & No Treatment & $\begin{array}{l}\text { Anti-rabies vaccine or RIG was not prescribed and the animal was observed for } \\
10 \text { days }\end{array}$ \\
\hline & PEP Treatment 1 & $\begin{array}{l}\text { Maximum three doses of mouse-brain vaccine on alternate days or even two } \\
\text { doses of cell culture vaccine on day } 0 \text { and } 3 \text { during animal observation }\end{array}$ \\
\hline & PEP Treatment 2 & $\begin{array}{l}\text { Seven consecutive doses and two boosters of mouse-brain vaccine or five doses of } \\
\text { cell culture vaccine on days } 0,3,7,14 \text { and } 28\end{array}$ \\
\hline & PEP Treatment 3 & $\begin{array}{l}\text { RIG + ten doses with three boosters of mouse brain vaccine or RIG + five doses } \\
\text { of cell culture vaccine }\end{array}$ \\
\hline & Revaccination & $\begin{array}{l}\text { The victim had been previously vaccinated against rabies and a booster was } \\
\text { recommended }\end{array}$ \\
\hline & Not rated & The number of doses prescribed was not compatible with the official treatment \\
\hline & No Information & There was no information on the treatment given \\
\hline \multirow{4}{*}{ 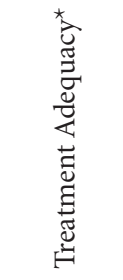 } & Appropriate & $\begin{array}{l}\text { Medical conduct followed adequately the technical standards recommended for } \\
\text { the type of exposure in order to avoid the risk of contracting rabies }\end{array}$ \\
\hline & Inappropriate & $\begin{array}{l}\text { Treatment did not follow the technical recommendations based on the type of } \\
\text { the exposure }\end{array}$ \\
\hline & Inconclusive & $\begin{array}{l}\text { There was two or more missing information regarding the animal and nature of } \\
\text { injury, making it impossible to evaluate the treatment }\end{array}$ \\
\hline & No Information & There was no information on the treatment given. \\
\hline
\end{tabular}

${ }^{\star}$ According to Rigo and Honer ${ }^{9}$.

Araçatuba (SP) was classified as not controlled rabies epidemiological status for from 1990 to 1996 because hundreds of canine rabies cases were reported in most counties in the area where it is located (northwestern region of the São Paulo State), and as controlled rabies epidemiological situation of from 1997 to 2010 when there were no cases of canine rabies in the town (only one case in a cat transmitted by vampire bat $)^{13,15}$, annual dogs and cats vaccination was over $80 \%$ of the population and rabies surveillance was applied.

The study included only records of dogs and cats aggressions in rural and urban areas, excluding the pre-exposure records. Of the total, 352 records $(4.2 \%)$ were inconsistent and were not analyzed. These files were incomplete, without treatment information or the treatment prescribed was different from the one recommended by the technical standards of human rabies prophylaxis $^{14}$.

Microsoft Access ${ }^{\circledR} 2007$ software was used for data entry and the results were reported as percentage values. The chi-square test with $5 \%$ significance level was used to compare the percentage of inappropriate adopted conducts (no treatment and indicated treatments) in both periods (1990-1996 and 1997-2010) by mean of Software BioEstat ${ }^{\circledR}$ 5.0.

\section{Results}

A total of 8,386 aggression records caused either by dogs or cats were analyzed during the studied period, an average of 399 cases per year of anti-rabies post-exposure care with the highest number $(1,844)$ occurring in 1994 (Figure 1).

Considering the epidemiological situation, $3,780(45.1 \%)$ of the total notifications were recorded during the period of 1990-1996 (not controlled rabies) with an average of 540/year; 4,606 (54.9\%) was registered during the period of 1997-2010 (controlled rabies), with an average of 329 per year.

The aggressions occurred predominantly by dogs with $89.1 \%(7,476 / 8,386)$ and the clinical status of the animal at the time of the attack was 
considered healthy in $75.4 \%(6,324 / 8,386)$ of cases.

The highest number of aggressions was registered in children ( $<1$ to 9 years old) with $28.3 \%$ $(2,377 / 8,386)$ of the cases. Regarding the gender, there was a slight predominance for males with $51.9 \%(4,350 / 8,386)$ of the victims.

The most common type of rabies exposure occurred via biting, corresponding to $(81.4 \%)$ $(7,399 / 9,088)$, which resulted predominantly in single and superficial wounds corresponding to $66.5 \%$ and $54.2 \%$ respectively (Table 1 ). A variation on the total number of wounds can be observed because a same victim could present different types of exposure and multiples wounds.

According to the exposure and injuries characteristics (Chart 1), 76.4\% (6,410/8,386) of the cases were considered as mild, $22.7 \%$ $(1,903 / 8,386)$ as severe and, in only $0.9 \%$ $(73 / 8,386)$ of the cases there was no information available for classification, which is essential to determine the most appropriate prophylactic conduct for rabies post-exposure in humans. Location of the aggressions were mostly in lower members $(33 \%)$ followed by the upper limbs (27.1\%).

From a total of 8,034 cases with the assessed conduct, in 4,267 (53.1\%) PEP treatment was not required. In the not controlled period (1990-
Table 1. Number and percentage of aggressions registered during the period of 1990-2010, according to the wounds characteristic and type, exposure type and aggressor animal EHSD, Araçatuba, SP, 2014.

\begin{tabular}{lrr}
\hline \multicolumn{1}{c}{ Wound type } & N & \% \\
Single & 5577 & 66.5 \\
Multiples & 2699 & 32.2 \\
Not filled & 110 & 1.3 \\
Characteristic of the wound & $\mathbf{N}$ & $\%$ \\
Deep & 3260 & 38.9 \\
Superficial & 4542 & 54.2 \\
Tearing & 126 & 1.5 \\
Not filled & 702 & 8.1 \\
Type of exposure & $\mathbf{N}$ & $\%$ \\
Contact & 383 & 4.2 \\
Scratch & 1078 & 11.9 \\
Licking & 154 & 1.7 \\
Bite & 7399 & 81.4 \\
Not filled & 74 & 0.8 \\
Location of aggression & $\mathbf{N}$ & $\%$ \\
Mucosa & 41 & 0.4 \\
Head / neck & 1149 & 12.5 \\
Hands / feet & 1939 & 21.1 \\
Upper body & 481 & 5.2 \\
Upper limbs & 2490 & 27.1 \\
Lower members & 3036 & 33.0 \\
Not filled & 68 & 0.7 \\
Aggressor species & $\mathbf{N}$ & $\%$ \\
Canine & 7476 & 89.1 \\
Feline & 910 & 10.9 \\
\hline
\end{tabular}

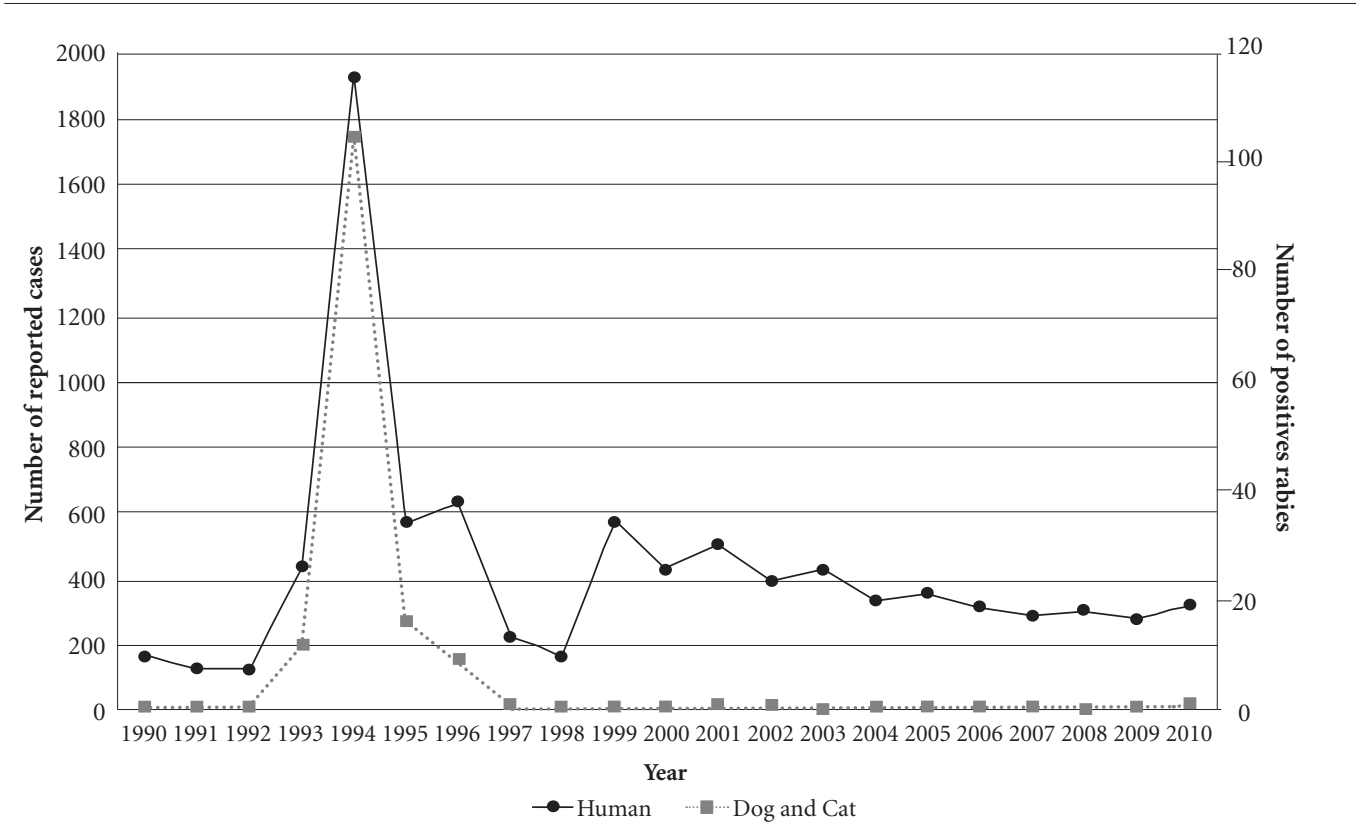

Figure 1. Number of reported human rabies post-exposure treatment per year during controlled (gray line) and not controlled rabies periods (black line) and number of positive rabies cases in dogs and cats. EHSD, Araçatuba, SP, 2014. 
1996), no treatment was adopted in 52.8\% $(1,951 / 3,692)$ of the cases, whereas in the controlled rabies period (1997-2010), no treatment was indicated in $53.3 \%(2,316 / 4,342)$ of the cases. This conduct was considered appropriate in $99.9 \%(1,949 / 1,951)$ of the cases in the first considered period and in 99.2\% (2,298/2,316) of the cases, in the second period (Figure 2). The difference in the number of times in which the no treatment was adopted appropriately in both periods was statistically significant $(\mathrm{p}=0.0013)$ by qui-schare test.

From the total of evaluated data during the period of 1990-2010, in 46.9\% $(3,767 / 8,034)$ of cases, some type of PEP treatment was indicated, and $64.6 \%(2,432 / 3,767)$ of those was inappropriate. The percentage of people attacked by dogs/cats which received any kind of treatment in the not controlled rabies period $(47.2 \%)$ did not differ $(\mathrm{p}=0,6574)$ from the controlled rabies period $(46.7 \%)$.

The analysis of the most recommended PEP treatment according to rabies epidemiological status of the area showed that, in the period of not controlled rabies (1990-1996), the most frequently prescribed treatment with $43.4 \%$
(756/1,741), was the application of RIG and 10 doses of mouse brain vaccine with 3 boosters (PEP treatment 3). Moreover, in the period of controlled rabies (1997-2010), the most frequent PEP treatments with $76.5 \%(1,550 / 2,026)$ were either the application of three doses of mouse brain vaccine or two doses of cell culture vaccine every other day (PEP Treatment 1) during the animal observation period.

The most inappropriate PEP treatments (Figure 3) were: PEP 3, followed by PEP1 in both periods, and PEP 2, in the period of 1990-1996 (not controlled rabies). During the period when the disease was controlled (1997-2010), revaccination was inappropriately recommended in $66.7 \%$ $(2 / 3)$ of cases, showing a statistic significant difference from the previous period $(\mathrm{p}=0.0434)$. However, this difference may be due to the small number of times this procedure was indicated.

Recommendation of PEP 1 was not statistically different $(p=0.1256)$ between the two periods. Recommendation of PEP 2 differed the most between the two periods $(\mathrm{p}<0.0001)$, but it was the most appropriate one for the controlled rabies period, with only 19\% (75/395) of error whereas in the not controlled period this treat-

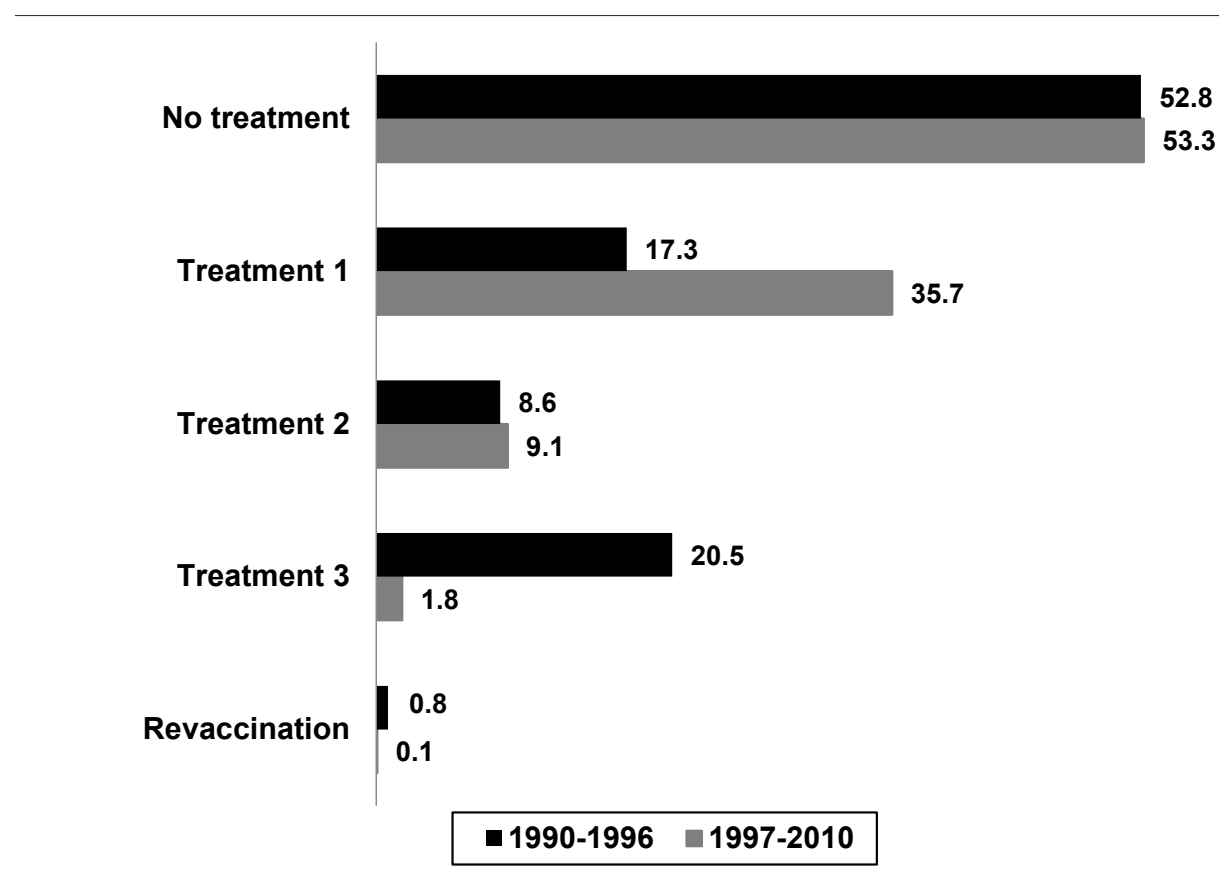

Figure 2. Percentage of cases according to the adopted rabies post-exposure prophylaxis conducts during the period of 1990-1996 (not controlled) and 1997-2010 (controlled rabies period) (Chart 1). EHSD, Araçatuba, SP, 2014. 


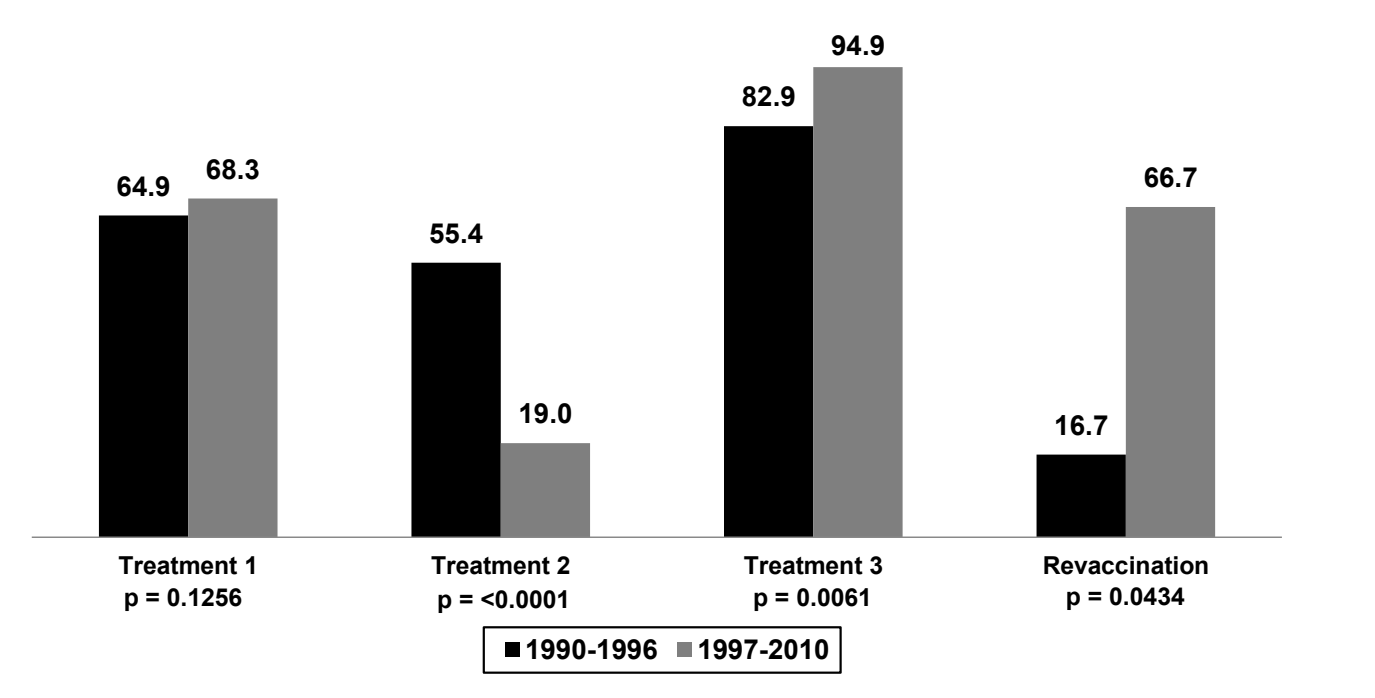

Figure 3. Percentage of post-exposure treatments considered inappropriate during not controlled (1990-1996) and controlled (1997-2010) rabies periods. EHSD, Araçatuba, SP, 201.

ment was inappropriately indicated in $55,4 \%$ $(175 / 316)$ of the cases. Therefore, during the not controlled rabies period, the recommended treatments were considered more inadequate (over 55\%), except for revaccination (16.7\%).

In general, the adopted conducts (no treatment or indication of treatment) were considered mostly appropriate for both periods, with $66.8 \%$ $(2,468 / 3,692)$ of cases in the not controlled period and $71.7 \%(3,114 / 4,342)$ in the controlled rabies period. Even resulting in a small difference in the percentage among periods, it was statistically significant $(\mathrm{p}<0.0001)$.

\section{Discussion}

In a 21 year period (1990-2010) PEP treatment was applied in 46,9\% $(3,767 / 8034)$ of the persons from Araçatuba town exposed to dogs and cats aggression and these procedures did not differ between periods when rabies was not controlled or when was controlled in the area.

The reduction in the number of animal rabies cases, or the control of urban rabies in a certain area, should result in a concomitant reduction in the number of rabies PEP treatments of humans exposed to animals aggressions or to animals suspected to be rabid as stated by Nunan et al. ${ }^{16}$. Additionally, sometimes the adopted procedure did not properly follow the official guide- lines resulting in unnecessarily prescription of vaccine or $\mathrm{RIG}^{8-10}$ besides financial costs for the government ${ }^{17}$.

As we expected there were a higher number of aggressions recorded annually in the period of not controlled rabies than in the controlled period, however, the number of appropriate conducts differed among the periods and despite the epidemiological situation of endemic canine rabies, the conduct of no treatment was adopted appropriately in most of the cases.

We observed that the highest number of aggressions recorded in 1994, occurred when the highest number of canine rabies in Araçatuba, SP (105 cases $)^{13}$ was registered. The increasing number of notifications observed in the early period of controlled rabies (1999) could be related to the beginning of visceral leishmaniasis in the municipality in 1998, and the record of one human case of this disease in $1999^{18}$. This fact probably led the population to search more often for health care after canine aggressions due to the fear of contracting diseases from them.

In similar studies, carried out in Brazil, the dog was pointed as the most common aggressor and most of them were also healthy at the time of aggression ${ }^{7,10,19-24}$. Rabies exposures occurring mostly via dog biting were also observed in the cities of São Paulo (SP) and Campo Grande $(\mathrm{MS})^{8,19}$ and can be relevant because, in addition to the physical trauma and high risk of rabies 
virus infection, bites can also transmit several diseases, especially caused by both aerobic and anaerobic bacteria ${ }^{25,26}$.

A higher frequency of aggressions characterized by single and superficial wounds was observed in our study, suggesting either self-defense or territory defense by the animal. Probably, the attack was a reaction to any kind of stimulus caused by the victims who, in most of the cases were the animal owners ${ }^{22,27}$.

A high percentage of healthy animals at the time of the aggression and the fact that the wounds were predominantly minor justify the approach of recommending no treatment, which was also the most common approach in other Brazilian municipalities ${ }^{7,8,21,22,28}$. Nevertheles, this conduct was the least used in cities like Salgueiro (PE), Jaboticabal (SP) and Porto Alegre (RS) in which recommendation of no treatment was chosen only in $10.6 \%{ }^{19}, 18.4 \%^{20}$ and $21.9 \%{ }^{11}$ of the cases, respectively. Considering the entire Brazilian country, the conduct of no treatment plus observing the aggressor animals for ten days was adopted in only $23.2 \%$ of cases ${ }^{6}$.

In Brazil, the implementation of rabies control measures significantly decreased the number of cases in humans and animals. However, as occurred in Ontario ${ }^{17}$ the number of PEP treatment in patients did not decrease proportionally as the rates remain above $50 \%$, resulting in unnecessary expenditures ${ }^{29}$.

In the period of 1990-1996 there was an outbreak of animal rabies in the studied area ${ }^{12}$, and therefore, some level of uncertainty might have prevented the adoption of the 10-day observation period of the animal and consequently, the recommendation of no treatment in accordance to the present technical manual ${ }^{14}$. By the other hand, even after the disease control in the studied area (1997-2010), the most prescribed treatments $(76.5 \%)$ were the application of two or three doses of vaccine every other day during the animal observation period, higher than observed by other authors ${ }^{21,30}$.

During the controlled rabies period the adopted conducts, in general, were more appropriate compared to the not controlled period. Similar researches developed in other Brazilian cities as Jaboticabal (SP), Campo Grande (MS) and Porto Alegre (RS), pointed that most of the adopted conducts were appropriate ${ }^{8,9,11}$, even when the vaccine and RIG treatment was indicated too often, as in the case of Araçatuba, SP.

\section{Conclusion}

Considering the different epidemiological rabies status in Araçatuba, SP, recommendation of using or not PEP treatments was considered adequate in most cases. Post exposure prophylaxis treatment was not recommended in most of the aggression cases and this was the appropriated conduct during the period of not controlled rabies. Among the recommended treatments, the most inappropriate one consisted of PEP Treatment 3, resulting in excessive application of RIG and rabies vaccine.

These results reinforce the need for a better evaluation of the risk factors involved in rabies infection and which treatment is more appropriate to avoid unnecessary immunization and RIG application, which might result adverse reactions in addition to unnecessary expenditures by the health service.

\section{Collaborations}

BFMC Andrade conception and experimental design, analysis and interpretation of the data, preparation of the manuscript; TSM Andrade tabulation of the data, exportation and statistical analysis; LH Queiroz conception and experimental design, analysis and interpretation of the data; revision of the manuscript in Portuguese and English.

\section{Acknowledgments}

We thanks the Epidemiological and Health Surveillance Department (EHSD) of Araçatuba and Lucila Bistaffa for providing the data to this study, Professor Silvia Helena Venturolli Perri for contributing to the statistical analysis and Professor Caris Maroni Nunes for the values contribution on manuscript revision. 


\section{References}

1. Jackson AC. Rabies. Curr Treat Options Infect Dis 2003; 5:35-40.

2. Acha PN, Szyfres B. Rabia. Zoonosis y Enfermedades Transmisibles Comunes al Hombre y a los Animales. 3a ed. Washington: Organización Panamericana de la Salud; 2003.

3. Costa WA, Avila CA, Valentine EJG, Reichmann MLAB, Cunha RS, Guidolin R, Omoto TM, Bolzan VL. Manual Técnico do Instituto Pasteur n.4 - Profilaxia da raiva humana. 2a ed. São Paulo: Instituto Pasteur; 2000.

4. Hampson K, Coudeville L, Lembo T, Sambo M, Kieffer A, Attlan M, Barrat J, Blanton JD, Briggs DJ, Cleaveland S, Costa P, Freuling CM, Hiby E, Knopf L, Leanes F, Meslin FX, Metlin A, Miranda ME, Müller T, Nel LH, Recuenco S, Rupprecht CE, Schumacher C, Taylor L, Vigilato MA, Zinsstag J, Dushoff J; Global Alliance for Rabies Control Partners for Rabies Prevention. Estimating the Global Burden of Endemic Canine Rabies. PloS Negl Trop Dis 2015; 9(5):e0003786.

5. Casagrande DKA, Favaro ABBBC, Carvalho C, Picolo MR, Hernanzez JCB, Lot MS, Albas A, Araújo DB, Pedro WA, Queiroz LH. Rabies surveillance in bats in Northwetern State of São Paulo. Rev Soc Bras Med Trop 2014; 47(6):709-715.

6. Wada MY, Rocha SM, Maia-Elkhoury ANS. Situação da raiva no Brasil, 2000 a 2009. Epidemiol Serv Saúde 2011; 20(2):509-518.

7. Kotait I, Carrieri ML, Takaoka NY. Manual Técnico do Instituto Pasteur n.8 - Raiva - Aspectos gerais e clínica. São Paulo: Instituto Pasteur; 2009.

8. Carvalho WO, Soares DFPP, Franceschi VCS. Características do atendimento prestado pelo serviço de profilaxia da raiva humana na rede municipal de saúde de Maringá - Paraná, no ano de 1997. Inf Epidemiol Sus 2002; 11(1):25-35.

9. Rigo L, Honer MR. Análise da profilaxia da raiva humana em Campo Grande, Mato Grosso do Sul, Brasil, em 2002. Cad Saúde Pública 2005; 21(6):1939-1945.

10. Moreira AAM, Lima MM. Conduta dos profissionais de saúde pública frente ao atendimento antirrábico humano no Município de Primavera do Leste-MT. Rev Epidemiol Control Infect 2013; 3(4):139-143.

11. Veloso RD, Aerts DRGC, Fetzer LO, Anjos CB, Sangiovanni JC. Perfil epidemiológico do atendimento antirrábico humano em Porto Alegre, RS, Brasil. Cien Saude Colet 2011; 16(12):4875-4884.

12. Queiroz LH, Carvalho C, Buso DS, Ferrari CIL, Pedro WA. Perfil epidemiológico da raiva na região Noroeste do estado de São Paulo no período de 1993 a 2007. Rev Soc Bras Med Trop 2009; 42(1):9-14.

13. Andrade AM, Queiroz LH, Perri SHV, Nunes CM. Estudo descritivo da estrutura populacional canina da área urbana de Araçatuba, São Paulo, Brasil, no período de 1994 a 2004. Cad Saúde Pública 2008; 24(4):4:297-932.

14. Brasil. Centro Nacional de Epidemiologia, Coordenação de Controle de Zoonoses e Animais Peçonhentos. Programa Nacional de Profilaxia da Raiva. Norma técnica de tratamento profilático anti-rábico humano. Brasília: Fundação Nacional de Saúde; 1994.

15. Queiroz LH, Favoretto SR, Cunha SEM, Campos ACA, Lopes M C, Carvalho C, Iamamoto K, Araújo DB, Venditti LL, Ribeiro ES, Pedro WA, Durigon EL. Rabies in southeast Brazil: a change in the epidemiological pattern. Arch Virol 2012; 157:93-105.
16. Nunan CP, Tinline RR, Honig JM, Ball G, Hauschildt P, LeBer CA. Postexposure treatment and animal rabies, Ontario, 1958-2000. Emerg Infect Dis 2002; 8(2):214-217.

17. Middleton D, Johnson KO, Rosatte RC, Hobbs JL, Moore SR, Rosella L, Crowcroft NS. Human Rabies Post-Exposure Prophylaxis and Animal Rabies in Ontario, Canada, 2001-2012. Zoonoses Public Health 2015; 62(5):356-364.

18. Galimbertti MZ, Katz G, Camargo-Neves VLF, Rodas LAC, Casanova C, Costa IP, Araújo MFL, Taniguchi HH, Barbosa JAR, Barbosa JE, Tolezano JE, Pinto PLS. Leishmaniose Visceral Americana no Estado de São Paulo. Rev Soc Bras Med Trop 1999; 32(Supl. 1):217-218.

19. Filgueira AC, Cardoso MD, Ferreira LOC. Profilaxia antirrábica humana: uma análise exploratória dos atendimentos ocorridos em Salgueiro-PE, no ano de 2007. Epidemiol Serv Saude 2011; 20:233-244.

20. Frias DRF, Lages SRL, Carvalho AAB. Avaliação da conduta de profilaxia antirrábica indicada para pessoas envolvidas em agravos com cães e gatos no município de Jaboticabal, SP, no período de 2000 a 2006. Rev Bras Epidemiol 2011; 14(4):722-732.

21. Garcia RCM, Vasconcellos AS, Sakamoto SM, Lopez AC. Análise de tratamento anti-rábico humano pós-exposição em região da Grande São Paulo, Brasil. Rev Saude Publica 1999; 33(3):295-301.

22. Müller GC, Seger J, Gabiatti LL. Avaliação dos casos de atendimento antirrábico humano notificados no município de São Miguel do Oeste - SC no ano de 2009. Unoesc \& Ciência - ACBS 2010; 1(2):95-105.

23. Poerner ALP. Tendência e características do atendimento antirrábico humano pós-exposição na Região CentroSul Fluminense, 2000-2005 [dissertação]. Rio de Janeiro: Universidade Federal Rural do Rio de Janeiro; 2007.

24. Rolim RLP, Lopes FMR, Navarro IT. Aspectos da vigilância epidemiológica da raiva no município de Jacarezinho, Paraná, Brasil, 2003. Semina: Cienc Agrarias 2006; 27(2):271-280.

25. Grieco RD, Rosen T, Orengo IF, Wolf JE. Dog, cat and human bites: a review. J Am Acad Dermatol 1995; 33(6):1019-1029.

26. Meyers B, Schoeman JP, Goddard A, Picard J. The bacteriology and antimicrobial susceptibility of infected and non-infected dog bite wounds: Fifty cases. Vet Microbiol 2008; 127(3-4):360-368.

27. Buso DS, Silva JE, Queiroz LH. Epidemiological aspects of dogs bite considering biter dogs and victims. Vet $e$ Zootec 2013; 20(3):296-306.

28. Pinto CL, Alleoni ES. Aspectos da vigilância epidemiológica da raiva em sub-regiões administrativas do estado de São Paulo, Brasil, 1982 - 1983. Rev Saude Publica 1986; 20(4):288-292.

29. Belotto AJ. Manual de Prevenção contra agressões por cães e gatos. São Paulo: Departamento Municipal de Saúde Pública; 2004.

30. Moreira AAM, Lima MM. Conduta dos profissionais de saúde pública frente ao atendimento antirrábico humano no Município de Primavera do Leste-MT. Rev Epidemiol Control Infect 2013; 3(4):139-143.

Artigo apresentado em 08/08/2016

Aprovado em 16/03/2017

Versão final apresentada em 18/03/2017 